\title{
Subtercola vilae sp. nov., a novel actinobacterium from an extremely high-altitude cold volcano lake in Chile
}

\author{
Alvaro S. Villalobos · Jutta Wiese • Pablo Aguilar • Cristina Dorador • \\ Johannes F. Imhoff
}

Received: 23 August 2017/Accepted: 1 December 2017/Published online: 6 December 2017

(C) The Author(s) 2017. This article is an open access publication

\begin{abstract}
A novel actinobacterium, strain DB165 ${ }^{\mathrm{T}}$, was isolated from cold waters of Llullaillaco Volcano Lake (6170 $\mathrm{m}$ asl) in Chile. Phylogenetic analysis based on 16S rRNA gene sequences identified strain $\mathrm{DB} 165^{\mathrm{T}}$ as belonging to the genus Subtercola in the family Microbacteriaceae, sharing $97.4 \%$ of sequence similarity with Subtercola frigoramans DSM $13057^{\mathrm{T}}$, $96.7 \%$ with Subtercola lobariae DSM $103962^{\mathrm{T}}$, and $96.1 \%$ with Subtercola boreus DSM $13056^{\mathrm{T}}$. The cells were observed to be Gram-positive, form rods with irregular morphology, and to grow best at $10-15{ }^{\circ} \mathrm{C}$, $\mathrm{pH} 7$ and in the absence of $\mathrm{NaCl}$. The cross-linkage
\end{abstract}

between the amino acids in its peptidoglycan is type B $2 \gamma$; 2,4-diaminobutyric acid is the diagnostic diamino acid; the major respiratory quinones are MK-9 and MK-10; and the polar lipids consist of phosphatidylglycerol, diphosphatidylglycerol, 5 glycolipids, 2 phospholipids and 5 additional polar lipids. The fatty acid profile of $\mathrm{DB} 165^{\mathrm{T}}(5 \%>)$ contains isoC14:0, iso-C16:0, anteiso-C15:0, anteiso-C17:0, and the dimethylacetal iso-C16:0 DMA. The genomic DNA $\mathrm{G}+\mathrm{C}$ content of strain DB165 ${ }^{\mathrm{T}}$ was determined to be $65 \mathrm{~mol} \%$. Based on the phylogenetic, phenotypic, and chemotaxonomic analyses presented in this
A1 A. S. Villalobos · J. Wiese - J. F. Imhoff ( $\square)$

A2 Marine Microbiology, GEOMAR Helmholtz Centre for

A3 Ocean Research Kiel, Düsternbrooker Weg 20,

A4 24105 Kiel, Germany

A5 e-mail: jimhoff@geomar.de

A6 A. S. Villalobos

A7 e-mail: avillalobos@geomar.de

A8 J. Wiese

A9 e-mail: jwiese@geomar.de

A10 P. Aguilar - C. Dorador

A11 Laboratorio de Complejidad Microbiana y Ecología

A12 Funcional and Departamento de Biotecnología, Facultad

A13 de Ciencias del Mar y Recursos Biológicos, Universidad

A14 de Antofagasta, Antofagasta, Chile

A15 e-mail: pablo.aguilar-espinosa@uibk.ac.at
A16 P. Aguilar

A17 Lake and Glacier Ecology Research Group, Institute of

A18 Ecology, University of Innsbruck, Techniker Str. 25,

A19 6020 Innsbruck, Austria

A20 C. Dorador

A21 Centre for Biotechnology and Bioengineering (CeBiB),

A22 Universidad de Antofagasta, Antofagasta, Chile

A23 e-mail: cristina.dorador@uantof.cl 
study, strain $\mathrm{DB}_{165^{\mathrm{T}}} \quad\left(=\mathrm{DSM} \quad 105013^{\mathrm{T}}=\mathrm{JCM}\right.$ $32044^{\mathrm{T}}$ ) represents a new species in the genus Subtercola, for which the name Subtercola vilae sp. nov. is proposed.

Keywords Cold environments · Llullaillaco volcano $\cdot$ Microbacteriaceae $\cdot$ New species . Subtercola vilae

\section{Introduction}

Members of the family Microbacteriaceae are widely distributed in terrestrial and aquatic environments or associated with macroorganisms (Evtushenko 2012). Some representatives, including species of the genus Subtercola, have been found in cold environments such as glacial ice (Christner et al. 2007), boreal groundwater (Männistö et al. 2000), and Antarctic sediments ( $\mathrm{Li}$ et al. 2010). At present the genus Subtercola contains three validly named species, Subtercola boreus, Subtercola frigoramans and Subtercola lobariae; the first two were isolated from Finnish groundwater (Männistö et al. 2000) and the third from the lichen Lobaria retigera (Si et al. 2017). Based on the high similarity of 16S rRNA gene sequences ( $>96 \%$ ), other isolates from cold habitats, such as Antarctic and Artic waters as well as glaciers were found to be affiliated to Subtercola (Singh et al. 2014; Zhang et al. 2013; Peeters et al. 2011).

In this study, we characterise strain $\mathrm{DB} 165^{\mathrm{T}}$, isolated from a water sample of Llullaillaco Volcano Lake $(6170 \mathrm{~m})$ in Chile, one of the highest-elevation lakes on Earth. According to its distinct properties, strain DB $165^{\mathrm{T}}$ is proposed as the type strain of the new species Subtercola vilae.

\section{Materials and methods}

Isolation and cell morphology

Strain DB $165^{\mathrm{T}}$ was obtained from a water sample collected at the Llullaillaco volcano lake $\left(\mathrm{S} 24^{\circ} 42.878^{\prime}\right.$, W68 $\left.33.310^{\prime}\right)$ on 18 January 2013, using R2A medium (DIFCO) supplemented with $18 \mathrm{~g}$ agar $1^{-1}$. Pure cultures were obtained after three successive transfers of single colonies to R2A medium plates. Stock cultures were maintained in SGG medium containing $10 \mathrm{~g}$ starch, $10 \mathrm{~g}$ glucose, $10 \mathrm{ml}$ glycerol $(99.7 \% \mathrm{v} / \mathrm{v}), 5 \mathrm{~g}$ soy peptone, $2.5 \mathrm{~g}$ corn steep solids, $2 \mathrm{~g}$ yeast extract, $3 \mathrm{~g} \mathrm{CaCO}_{3}, 1 \mathrm{~g} \mathrm{NaCl}$, and $18 \mathrm{~g}$ agar in 11 deionised water (Goodfellow and Fiedler 2010). DB165 ${ }^{\mathrm{T}}$ was cryopreserved using CRYOBANK (Mast Diagnostica GmbH, Germany) for long term storage at $-80{ }^{\circ} \mathrm{C}$.

Gram-staining was prepared using the Color Gram 2 kit (BioMérieux, France), following the manufacturer's protocol. Endospore staining was performed using the green malaquite method and light microscopy (Schaeffer and Fulton 1933). Cell morphology, shape and size were determined using scanning electron microscopy (SEM) according to Gärtner et al. (2008), after cultivation of trypticase soy medium (Trypticase Soy Broth (Becton, Dickinson and company, France) supplemented with $18 \mathrm{~g}$ agar $1^{-1}$.

The reference strains $S$. boreus DSM $13057^{\mathrm{T}}$ and $S$. frigoramans DSM $13057^{\mathrm{T}}$ were obtained from the German Collection of Microorganisms and Cell Cultures (DSMZ) and cultured under the same conditions as strain $\mathrm{DB} 165^{\mathrm{T}}$ for comparative purposes.

Physiological characteristics

Enzyme activities and utilisation of carbon sources for strain DB165 ${ }^{\mathrm{T}}, S$. boreus DSM $13057^{\mathrm{T}}$ and $S$. frigoramans DSM $13057^{\mathrm{T}}$ were examined using API ZYM, API 20E and API 50CH (BioMérieux, France), following the manufacturer's recommendations. The effect of sodium chloride $(0,0.1,0.3,0.6,0.9,1,2.5,5$, 7.5 , and $10 \% \mathrm{w} / \mathrm{v})$ and $\mathrm{pH}(2,3,4,5,6,7,8,9$ and 10) on the growth was tested according to Kutzner (1981), using ISP2 medium containing $4 \mathrm{~g}$ yeast extract, $10 \mathrm{~g}$ malt extract, $4 \mathrm{~g}$ dextrose, and $18 \mathrm{~g}$ agar in $11 \mathrm{of}$ distilled water. The optimal range of temperature was tested at $5,10,15,20,28$ and $30^{\circ} \mathrm{C}$ using SGG medium.

\section{Chemotaxonomic analyses}

Polar lipids were extracted according to a modified protocol of Bligh and Dyer (1959), and the total lipid material was detected using molybdatophosphoric acid and specific functional groups were detected using spray reagents specific for defined functional groups (Tindall et al. 2007). The lipoquinones were 
extracted and identified using the two-stage method described by Tindall (1990a, b). After cultivation at $25^{\circ} \mathrm{C}$, fatty acid methyl esters were obtained by saponification, methylation and extraction using minor modifications of the method of Miller (1982) and Kuykendall et al. (1988) The fatty acid methyl esters mixtures were separated and identified using the Sherlock Microbial Identification System (MIS) (MIDI, Microbial ID, Newark, DE 19711, USA).

The peptidoglycan was obtained from $4 \mathrm{~g}$ wet weight cell pellet according to the method of Schleifer (1985). The peptidoglycan analyses were performed according to Schumann (2011).

Analyses of polar lipids, respiratory quinones, whole-cell fatty acids and peptidoglycan analyses were carried out by the Identification Service of the DSMZ_-Deutsche Sammlung von Mikroorganismen und Zellkulturen GmbH (Braunschweig, Germany).

DNA base composition

DNA was extracted using the DNeasy Blood \& Tissue kit (QIAGEN). The G+C content was calculated from the genome sequence, which was determined with Nextseq 500 (Illumina). The quality of the sequences was checked and filtrated using Trimmomatic (adapters, > Q30, > 1000 bp) (Bolger et al. 2014). The genome was assembled using SPAdes $($ Kmer $=121)$ (Bankevich et al. 2012).

Phylogenetic analyses

DNA was extracted using the DNeasy Blood \& Tissue kit (QIAGEN) with modifications. The 16S rRNA gene sequence was amplified by PCR using PureTaq Ready-To-Go PCR beads (GE Healthcare) and sequencing according to Gärtner et al. (2008).

The 16S rRNA gene sequence of strain DB $165^{\mathrm{T}}$ was aligned with sequences of 22 selected type strains of the family Microbacteriaceae, including members of the genera Subtercola, Frondihabitans and Agreia, and in addition Cellulomonas carbonis KCTC $19824^{\mathrm{T}}$ as outgroup using SINA (Pruesse et al. 2012). Phylogenetic trees were constructed using the neighbour-joining (Saitou and Nei 1987) and maximumlikelihood algorithms using MEGA version 6.0 (Tamura et al. 2013). The tree topologies were evaluated with bootstrap analyses based on 1000 replicates.

\section{Results}

Morphological and physiological characteristics

Colonies of strain DB $165^{\mathrm{T}}$ were observed to be sticky, golden yellow after growth at the optimal growth temperature of $10-15^{\circ} \mathrm{C}$ for $6-7$ days (also after $7-10$ days at $28{ }^{\circ} \mathrm{C}$ ), but are pale yellow after growth at $5{ }^{\circ} \mathrm{C}$ for 2-3 weeks. Optimum growth is observed at $10-15{ }^{\circ} \mathrm{C}$ (range from 5 to $28^{\circ} \mathrm{C}$ ). No growth occurs at $30{ }^{\circ} \mathrm{C}$. Strain DB $165^{\mathrm{T}}$ tolerates only low concentrations (up to $0.9 \%$ ) of $\mathrm{NaCl}$ and grows best in the absence of $\mathrm{NaCl}$. The $\mathrm{pH}$ range for growth is from 5 to 8 , with an optimum at $\mathrm{pH} 7$. Cells show no motility and form no spores, they are irregular short rods of $0.5 \mu \mathrm{m}$ width and 1.0-1.2 $\mu \mathrm{m}$ length, Gram-positive and have an irregular shape as seen under SEM. Some of the cells are thicker at the ends. Occasionally, coccoid cells were observed (Fig. 1). Variable cell shapes have also been reported for $S$. boreus and S. frigoramans (Männistö et al. 2000).

The metabolic properties of strain $\mathrm{DB} 165^{\mathrm{T}}$, in comparison with the type strains of $S$. boreus and $S$. frigoramans are shown in Table 1 . Strain $\mathrm{DB} 165^{\mathrm{T}}$ was found to metabolise inositol, D-sorbitol, D-sucrose, Dmelibiose, glycerol, L-arabinose, D-xylose, methyl- $\beta$ D-xylopyranoside, D-galactose, D-glucose, D-fructose, D-mannose, L-rhamnose, D-mannitol, amygdalin,

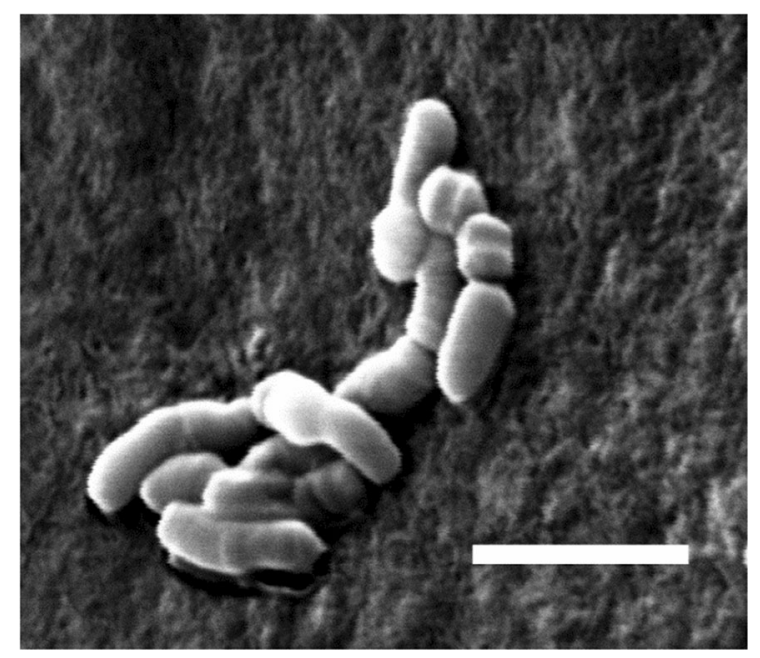

Fig. 1 Scanning electron micrograph of strain $\mathrm{DB} 165^{\mathrm{T}}$ grown on trypticase soy medium for 7 days at $28^{\circ} \mathrm{C}$. Scale bar indicates $2 \mu \mathrm{m}$ 
Table 1 Physiological characteristics of strain DB165 ${ }^{\mathrm{T}}$ compared to the type strains of S. frigoramans and S. boreus

\begin{tabular}{|c|c|c|c|}
\hline & $\begin{array}{l}\text { S. vilae } \\
\text { DB } 165^{\mathrm{T}}\end{array}$ & $\begin{array}{l}\text { S. frigoramans } \\
\text { DSM } 13057^{\mathrm{T}}\end{array}$ & $\begin{array}{l}\text { S. boreus } \\
\text { DSM } 13056^{\mathrm{T}}\end{array}$ \\
\hline \multicolumn{4}{|l|}{ APIZYM } \\
\hline Alkaline phosphatase & - & $(+)$ & + \\
\hline Esterase (C4) & + & $(+)$ & + \\
\hline Valine arylamidase & $(+)$ & $(+)$ & + \\
\hline Cysteine arylamidase & $(+)$ & - & + \\
\hline Trypsin & $(+)$ & - & - \\
\hline$\alpha$-Galactosidase & $(+)$ & - & - \\
\hline$\beta$-Glucoronidase & - & - & + \\
\hline$n$-Acetyl- $\beta$-glucosaminidase & - & $(+)$ & - \\
\hline$\alpha$-Mannosidase & - & $(+)$ & $(+)$ \\
\hline \multicolumn{4}{|l|}{ API20E } \\
\hline Arginine dihydrolase & - & $(+)$ & - \\
\hline Citrate as unique carbon source & - & $(+)$ & $(+)$ \\
\hline Tryptophan deaminase & + & - & - \\
\hline Tryptophanase & + & - & - \\
\hline Voges-Proskauer test (production of acetoin) & + & - & - \\
\hline \multicolumn{4}{|l|}{ API $50 \mathrm{CH}$} \\
\hline D-Arabinose & - & - & + \\
\hline D-Ribose & - & - & + \\
\hline Methyl- $\beta$-D-xylopyranoside & + & - & - \\
\hline D-Mannose & + & - & + \\
\hline Arbutin & + & - & - \\
\hline Salicin & + & - & - \\
\hline D-Lactose (bovine origin) & - & - & + \\
\hline D-Melezitose & + & - & - \\
\hline Gentiobiose & + & - & - \\
\hline
\end{tabular}

In the present study, all Subtercola strains showed positive activity in the tests for esterase lipase (C8), leucine arylamidase, acid phosphatase, Naphthol-AS-Bl-phosphohydrolase, $\alpha$-glucosidase, $\beta$-glucosidase, $\beta$-galactosidase (weak in API ZYM test), D-glucose, D-mannitol, inositol, D-sorbitol, L-rhamnose, D-sucrose, D-melibiose, amygdalin, L-arabinose, glycerol, D-xylose, D-galactose, Dfructose, esculin, D-cellobiose, D-maltose, D-trehalose and D-turanose; and negative activity for lipase (C14), $\alpha$-chymotrypsin, $\alpha$ fucosidase, lysine decarboxylase, ornithine decarboxylase, sulfide production, urease, gelatinase, erythritol, L-xylose, L-sorbose, dulcitol, methyl- $\alpha$-D-mannopyranoside, methyl- $\alpha$-D-glucopyranoside, $N$-acetylglucosamine, inulin, D-raffinose, starch, glycogen, xylitol, D-lyxose, D-tagatose, D-fucose, D-arabitol, L-arabitol, potassium gluconate, potassium 2-ketogluconate and potassium 5-ketogluconate

+ positive activity, $(+)$ weak activity, - no activity

arbutin, esculin, salicin, D-cellobiose, D-maltose, Dtrehalose, D-melezitose, gentiobiose and D-turanose.

\section{Chemotaxonomic characteristics}

The polar lipids of the strain $\mathrm{DB} 165^{\mathrm{T}}$ were found to consist of phosphatidylglycerol, diphosphatidylglycerol, 5 unidentified glycolipids, 2 unidentified phospholipids and unidentified 5 lipids. The diamino acid in the peptidoglycan was identified as 2,4diaminobutyric acid (DAB). The molar ratio of alanine:glycine:glutamic acid:DAB was 1.1:1.0:0.04:1.7. Instead of glutamic acid, high amounts of 3-hydroxyl-glutamic acid were found. Assuming that much of the glutamic acid is replaced by 3-hydroxyl-glutamic acid, and despite this 
replacement, the amino acid composition is consistent with peptidoglycan type B2 $\gamma$. The major isoprenoid quinones of strain DB165 ${ }^{\mathrm{T}}$ were identified as MK-9 (47\%) and MK-10 (39\%). Minor amounts of MK-11 $(6 \%)$ and MK-8 (4\%) were also found to be present. The $\mathrm{G}+\mathrm{C}$ content of the genomic DNA of the strain $\mathrm{DB} 165^{\mathrm{T}}$ was determined to be $65.0 \mathrm{~mol} \%$.

The major fatty acids of the strain $\mathrm{DB} 165^{\mathrm{T}}$ were identified as iso- and anteiso-saturated C15 and C16 fatty acids with anteiso-C15:0 (50\%), iso-C16:0 (17\%) and iso-C16:0 DMA (17\%) as major components (Table 2).

16S rRNA gene sequence analyses

The 16S rRNA gene sequence of strain DB $165^{\mathrm{T}}$ (1432 bp, deposited under Genbank accession number MF276890) matches to different Subtercola species in a range of $96.1-97.4 \%$ of similarity, i.e., S. frigoramans DSM $13057^{\mathrm{T}}$ (97.4\% similarity), S. lobariae DSM $103962^{\mathrm{T}}$ (96.7\% similarity) and $S$. boreus DSM $13056^{\mathrm{T}}$ (96.1\% similarity). However, it also showed high similarity to Frondihabitans species, including Frondihabitans peucedani DSM $22180^{\mathrm{T}}$ (96.8\% similarity) and Frondihabitans australicus DSM $17894^{\mathrm{T}}$ (96.6\% similarity). The phylogenetic analysis (Fig. 2) based on the consensus 16S rRNA gene sequences (1416 bp) showed that strain DB165 ${ }^{\mathrm{T}}$ forms a cluster with Subtercola species and Agreia with a strong bootstrap support, while Frondihabitans species cluster together, but the separation with the Subtercolal Agreia cluster is not well supported by bootstrap analysis. In the Subtercola clade, strain $\mathrm{DB} 165^{\mathrm{T}}$ is found in a distinct cluster with $S$. frigoramans DSM $13057^{\mathrm{T}}$ with strong bootstrap support.

Genome characteristics

The genome of strain DB $165^{\mathrm{T}}$ has a size of approx. $4 \mathrm{Mb}$ and give some hints on the strains' potential to adapt to the harsh conditions that are found at Llullaillaco volcano lake. These include mechanisms concerning membrane fluidity, biosynthesis of cryoprotectants, and ice-interacting proteins (data not shown).

\section{Discussion}

Subtercola species are characterised by a peptidoglycan type B2 $\gamma$ with DAB as diamino acid, MK-9 and MK-10 as major respiratory quinones, and a similar polar lipids profile (Table 3).

Strain DB $165^{\mathrm{T}}$ has a peptidoglycan type $\mathrm{B} 2 \gamma$ in which the glutamic acid is almost completely replaced by 3-hydroxyl-glutamic acid, as is found in other
Table 2 Fatty acid profiles of strain DB $165^{\mathrm{T}}, S$. frigoramans DSM $13057^{\mathrm{T}}$, S. boreus DSM $13056^{\mathrm{T}}$ and S. lobariae DSM $103962^{\mathrm{T}}$

Percent of total peak area of ion chromatograms is indicated

Cells for fatty acid and dimethyl acetals were grown at $25^{\circ} \mathrm{C}$, except for $S$. lobariae where DMAs were obtained from cells cultivated at $20{ }^{\circ} \mathrm{C}$

$\operatorname{Tr}$ traces $(<1 \%),-$ not detected, $a$ - anteisobranched fatty acid, $i$ - isobranched fatty acid, DMA 1,2 dimethyl acetals

\begin{tabular}{lllll}
\hline & $\begin{array}{l}\text { S. vilae } \\
\text { DB165 }\end{array}$ & $\begin{array}{l}\text { S. frigoramans } \\
\text { DSM 13057 }\end{array}$ & $\begin{array}{l}\text { S. boreus } \\
\text { DSM 13056 }\end{array}$ & $\begin{array}{l}\text { S. lobariae } \\
\text { DSM 103962 }\end{array}$ \\
\hline 14:0 & Tr & - & - & - \\
14:0 2-OH & - & - & - & 10.3 \\
16:0 & Tr & - & - & Tr \\
i-14:0 & 5.5 & 6.7 & $\operatorname{Tr}$ & 2.3 \\
i-15:0 & Tr & Tr & 4.3 & 1.4 \\
i-16:0 & 17.2 & 10.2 & 4.2 & 6.7 \\
i-17:0 & - & - & - & - \\
a-15:0 & 50.0 & 46.1 & 51.6 & 68.8 \\
a-17:0 & 6.7 & 6.8 & 3.5 & 4.2 \\
a-15:1 & - & - & $\operatorname{Tr}$ & - \\
16:0 DMA & Tr & - & $\operatorname{Tr}$ & - \\
i-15:0 DMA & $\operatorname{Tr}$ & - & 1.7 & 1.5 \\
i-16:0 DMA & 17.0 & 13.3 & 11.9 & 6.9 \\
a-15:0 DMA & 3.2 & 10.3 & 11.0 & 9.7 \\
a-17:0 DMA & 1.9 & 2.9 & 4.0 & 2.6 \\
References & This study & Männistö et al. (2000) & Männistö et al. (2000) & Si et al. (2017) \\
\hline
\end{tabular}




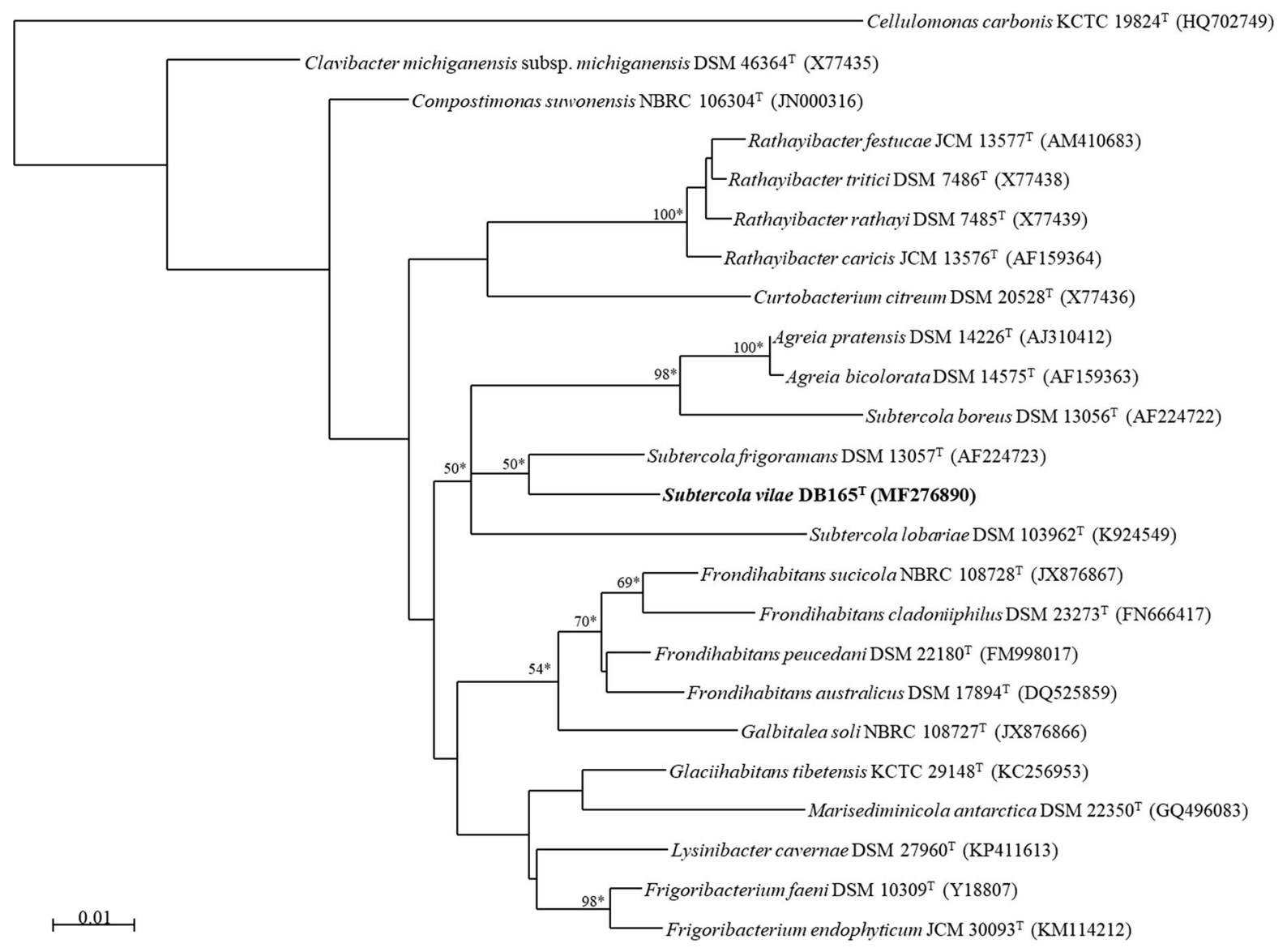

Fig. 2 Maximum-likelihood phylogenetic tree based on 16S rRNA gene sequence comparison of strain DB $165^{\mathrm{T}}$ and species of the family Microbacteriaceae with Cellulomonas carbonis KCTC $19824^{\mathrm{T}}$ as outgroup. Numbers at the nodes represent bootstrap support (\%) based on the analysis of 1000 bootstrap

described Subtercola species (Männistö et al. 2000; Si et al. 2017). The metabolic characteristics that differentiate strain DB $165^{\mathrm{T}}$ from $S$. boreus and $S$. frigoramans are utilisation of methyl- $\beta$-D-Xylopyranoside, arbutin salicin, D-melezitose and gentobiose as carbon sources and the enzymatic activities of trypsin, $\alpha$ galactosidase, tryptophanase deaminase and tryptophanase, as well as the production of acetoin. In contrast to strain $\mathrm{DB} 165^{\mathrm{T}}, S$. frigoramans exhibited as unique features arginine dihydrolase and $n$-acetyl- $\beta$ glucosaminidase. S. frigoramans and $S$. boreus can use citrate as unique carbon source and showed the enzymatic activities of alkaline phosphatase and $\alpha$ mannosidase. $S$. boreus showed $\beta$-glucoronidase enzymatic activity and can use D-arabinose, D-ribose, and D-lactose, carbon sources that strain $\mathrm{DB} 165^{\mathrm{T}}$ and replications, asterisks indicate branches of the tree that were also recovered using neighbour joining algorithm. Only bootstrap values $\geq 50 \%$ are indicated. Genbank accession numbers are given in parentheses. Bar indicates 0.01 substitutions per site

S. frigoramans cannot use. The fatty acid profile of strain DB $165^{\mathrm{T}}$ is similar to those of the type strains of other Subtercola species. Major differences were observed in the content of iso-C16:0, with $17 \%$ in strain DB $165^{\mathrm{T}}$ compared to $4.2-10.2 \%$ in the other Subtercola species and a low content of 3\% anteisoC15:0 DMA, compared to $9.7-11.0 \%$ in the other Subtercola species (Table 2).

The phylogenetic analysis of the $16 \mathrm{~S}$ rDNA gene sequence clearly shows the close relationship of strain $\mathrm{DB} 165^{\mathrm{T}}$ to Subtercola species rather than to Agreia and Frondihabitans species. The genus Agreia forms a sub-cluster within $S$. boreus (this study and $\mathrm{Si}$ et al. 2017) and different chemotaxonomic traits have been proposed to distinguish the two genera (Schumann et al. 2003). Though both genera have a cross-linkage 
Table 3 Diagnostic key characteristics of members of the genera Subtercola, Agreia, and Frondihabitans in comparison to strain $\mathrm{DB} 165^{\mathrm{T}}$

\begin{tabular}{|c|c|c|c|c|}
\hline & $\begin{array}{l}\text { Subtercola vilae } \\
\text { DB } 165^{\mathrm{T}}\end{array}$ & Subtercola & Agreia & Frondihabitans \\
\hline Peptidoglycan type & $\mathrm{B} 2 \gamma$ & $\mathrm{B} 2 \gamma$ & $\mathrm{B} 2 \gamma$ & $\mathrm{B} 2 \beta$ \\
\hline Cell wall diamino acid & DAB & DAB & $\begin{array}{l}\text { L-DAB } \\
\text { D-Orn }\end{array}$ & D-Orn \\
\hline Respiratory quinones & MK-9, MK-10 & MK-9, MK-10 & MK-10, MK-11 & MK-7, MK-8, MK-9 \\
\hline Polar lipids & $\begin{array}{l}\text { PG, DPG, GL, PL, } \\
\text { L }\end{array}$ & PG, DPG, GL, PL & PG, DPG & $\begin{array}{l}\text { PG, DPG, GL, AL, } \\
\text { PL }\end{array}$ \\
\hline $\begin{array}{l}\text { Major cellular fatty } \\
\text { acids }(>10 \%)\end{array}$ & $a-15: 0, i-16: 0$ & $a-15: 0, i-16: 0$ & a-15:0, i:16:0, a-17:0 & $\begin{array}{l}18: 1,14: 02-\mathrm{OH}, \\
\text { a-15:0 }\end{array}$ \\
\hline $\begin{array}{l}\text { Major 1,1-dimethyl } \\
\text { acetals }(>5 \%)\end{array}$ & i-16:0 DMA & i-16:0 DMA, a-15:0 DMA & ND & ND \\
\hline $\mathrm{G}+\mathrm{C}$ content $(\mathrm{mol} \%)$ & 65 & $64-68$ & $65-67$ & $65-71$ \\
\hline Isolation source & $\begin{array}{l}\text { Volcano lake at } \\
6170 \mathrm{~m} \text { asl }\end{array}$ & $\begin{array}{l}\text { Boreal groundwater, } \\
\text { lichen }\end{array}$ & $\begin{array}{l}\text { Leaf gall, phyllosphere of } \\
\text { grasses }\end{array}$ & $\begin{array}{l}\text { Associated to plants } \\
\text { and lichen }\end{array}$ \\
\hline References & This work & $\begin{array}{l}\text { Männistö et al. (2000), Si } \\
\text { et al. (2017) }\end{array}$ & $\begin{array}{c}\text { Evtushenko et al. (2001), } \\
\text { Behrendt et al. (2002) }\end{array}$ & Kim et al. (2014) \\
\hline
\end{tabular}

$P G$ phosphatidylglycerol, $D P G$ diphosphatidylglycerol, $G L$ glycolipids, $P L$ phospholipids, $A L$ aminolipid, $L$ lipids, $N D$ not detected

between the amino acids in the peptidoglycan of type B $2 \gamma$, in the case of Subtercola species, the crosslinkages have DAB, while Agreia species have L-DAB connected to D-Orn. Frondihabitans species can be clearly distinguished by their peptidoglycan, which is of the B2 $\beta$ type (Zhang et al. 2007). Fatty acids play an important role in the differentiation of the genera. The presence of 1,2 dimethyl acetals (iso-C16:0 DMA and anteiso-C17:0 DMA) is observed in all Subtercola species, while Agreia only contains iso-C15:0 DMA in low proportions $(\leq 4 \%)$ (Schumann et al. 2003; Behrendt et al. 2002). Frondihabitans species have a fatty acid profile very distinct from those of Subtercola and Agreia species, having $\mathrm{C} 18: 1$ and $\mathrm{C} 14: 02-\mathrm{OH}$ as major fatty acids but lacking 1,2 dimethyl acetals. The major menaquinones of Subtercola species, including the strain DB165 ${ }^{\mathrm{T}}$, comprise MK-9 and MK-10, while in Agreia bicolorata DSM $14575^{\mathrm{T}}$ MK-10 and in Agreia pratensis DSM $4246^{\mathrm{T}}$ MK-10 and MK-11 are dominant, and in Frondihabitans spp. MK-8 and MK7. The presence of MK-9 as a major component can be used as a marker to differentiate these three genera (Table 2). It should be mentioned that A. pratensis, which was originally classified as Subtercola pratensis, contains MK-10 (51\%) and MK-11 (21\%) as major menaquinones, but in addition $13 \%$ of MK-9
(Behrendt et al. 2002, Evtushenko et al. 2001). Irrespective of the problematic taxonomic position of Agreia species and the similarity of 16S rRNA gene sequences with Frondihabitans, the phylogenetic relationships (Fig. 2) and chemotaxonomic criteria clearly support the classification of strain $\mathrm{DB} 165^{\mathrm{T}}$ as a member of the genus Subtercola (Table 3). Based on the phenotypic and genetic analyses presented in this work, strain $\mathrm{DB} 165^{\mathrm{T}}$ is considered to represent a new species of the genus Subtercola, for which the name Subtercola vilae sp. nov. is proposed. The Digital Protologue database (Rosselló-Móra et al. 2017) TaxoNumber for strain DB $165^{\mathrm{T}}$ is TA00217.

\section{Description of Subtercola vilae sp. nov.}

Subtercola vilae (vi'lae, of Vila, named in honour of Irma Vila, a Chilean limnologist with outstanding contributions to the microbiology and ecology of lakes in the Chilean Altiplano and Atacama Desert).

Cells are short, irregular rods $0.5 \mu \mathrm{m}$ wide and 1.0-1.2 $\mu \mathrm{m}$ long. Colonies are golden yellow, circular convex. Growth occurs chemoheterotrophically under oxic conditions. Optimum growth is at $10-15{ }^{\circ} \mathrm{C}$ (range from 5 to $28{ }^{\circ} \mathrm{C}$ ), at $\mathrm{pH} 7$ (range from $\mathrm{pH} 5$ to 8 ) 
and in the absence of $\mathrm{NaCl}$. Cells produce esterase $\mathrm{C} 4$, esterase lipase $\mathrm{C} 8$, leucine arylamidase, acid phosphatase, naphthol-AS-BI-phosphohydrolase, $\alpha$ - and $\beta$ glucosidase, tryptophan deaminase, tryptophanase and acetoin. Weak activity is observed for valine arylamidase, cysteine arylamidase, trypsin, and $\alpha$ - and $\beta$ galactosidase. Carbon sources used under oxic conditions include inositol, D-sorbitol, D-sucrose, D-melibiose, glycerol, L-arabinose, D-xylose, methyl- $\beta$-Dxylopyranoside, D-galactose, D-glucose, D-fructose, Dmannose, L-rhamnose, D-mannitol, amygdalin, arbutin, esculin, salicin, D-cellobiose, D-maltose, D-sucrose, D-trehalose, D-melezitose, gentiobiose and Dturanose. The cell-wall peptidoglycan is type B2 $\gamma$ with $\mathrm{DAB}$ as the diagnostic amino acid and 3-hydroxylglutamic acid instead of glutamic acid. Major menaquinones are MK-9 and MK-10. Polar lipids comprise phosphatidylglycerol, diphosphatidylglycerol, 5 unidentified glycolipids, 2 unidentified phospholipids and 5 unidentified lipids. The major cellular fatty acids are anteiso-C15:0, iso-C16:0, anteisoC17:0, and iso-C14:0, while C14:0 and C16:0 are found only in traces. Major dimethylacetals are isoC16:0 DMA, anteiso-C15:0 DMA and anteiso-C17:0 DMA, while C16:0 DMA and iso-C15:0 DMA are present in trace amounts. The $\mathrm{G}+\mathrm{C}$ content of the DNA of the type strain is $65.0 \mathrm{~mol} \%$.

The type strain DB165 ${ }^{\mathrm{T}}\left(=\mathrm{DSM} 105013^{\mathrm{T}}=\mathrm{JCM}\right.$ $32044^{\mathrm{T}}$ ) was isolated from Llullaillaco volcano lake in Chile. The GenBank/EMBL/DBBJ accession number for the 16S rRNA of strain DB165 ${ }^{\mathrm{T}}$ is MF276890.

\begin{abstract}
Acknowledgements The authors gratefully acknowledge sequence analysis by the IKMB sequencing facility (University of Kiel, Germany), SEM sample preparation by Rolf Schmaljohann (GEOMAR, Kiel, Germany), providing of samples from Llullaillaco volcano by Thomas Bowen and Matt Ferson (California State University, USA) and genomic sequence analysis by Wiebke Sickel and Alexander Keller (University of Würzburg, Germany). Alvaro S. Villalobos thanks the ISOS supervisors Ute Hentschel Humeida (GEOMAR, Kiel, Germany) and Frank Sönnichsen (University Kiel, Germany) for fruitful discussions. He also is grateful for support by a doctoral fellowship from Becas Chile (CONICYT) and the Deutscher Akademischer Austausch Dienst (DAAD).
\end{abstract}

\section{Compliance with ethical standards}

Conflict of interest The authors declare that the research was conducted in the absence of any commercial or financial relationships that could be construed as a potential conflict of interest.
Open Access This article is distributed under the terms of the Creative Commons Attribution 4.0 International License (http:// creativecommons.org/licenses/by/4.0/), which permits unrestricted use, distribution, and reproduction in any medium, provided you give appropriate credit to the original author(s) and the source, provide a link to the Creative Commons license, and indicate if changes were made.

\section{References}

Bankevich A, Nurk S, Antipov D et al (2012) SPAdes: a new genome assembly algorithm and its applications to singlecell sequencing. J Comput Biol 19:455-477

Behrendt U, Ulrich A, Schumann P, Naumann D, Suzuki K (2002) Diversity of grass-associated Microbacteriaceae isolated from the phyllosphere and litter layer after mulching the sward; polyphasic characterization of Subtercola pratensis sp. nov., Curtobacterium herbarum sp. nov. and Plantibacter flavus gen. nov., sp. nov. Int J Syst Evol Microbiol 52:1441-1454

Bligh EG, Dyer WJ (1959) A rapid method of total lipid extraction and purification. Can $\mathrm{J}$ Biochem Physiol 37:911-917

Bolger AM, Lohse M, Usadel B (2014) Trimmomatic: a flexible trimmer for Illumina sequence data. Bioinformatics 30:2114-2120

Christner BC, Mosley-Thompson E, Thompson LG, Zagorodnov V, Reeve JN (2007) Isolation and identification of bacteria from ancient and modern ice core archives. In: Casassa G, Sepúlveda FV, Sinclair RM (eds) The Patagonian icefields: a unique natural laboratory for environmental and climate change studies. Springer, New York, pp 9-15

Evtushenko LI (2012) Family XI. Microbacteriaceae. In: Whitman W, Goodfellow M, Kämpfer P, Busse HJ, Trujillo M, Ludwig W, Suzuki KI, Parte A (eds) Bergey's manual of systematic bacteriology, volume 5: the actinobacteria. Springer, Berlin, pp 807-994

Evtushenko LI, Dorofeeva LV, Dobrovolskaya TG et al (2001) Agreia bicolorata gen. nov., sp. nov., to accommodate actinobacteria isolated from narrow reed grass infected by the nematode Heteroanguina graminophila. Int J Syst Evol Microbiol 51:2073-2079

Gärtner A, Wiese J, Imhoff JF (2008) Amphritea atlantica gen. nov., sp. nov., a gammaproteobacterium from the Logatchev hydrothermal vent field. Int J Syst Evol Microbiol 58:34-39

Goodfellow M, Fiedler H-P (2010) A guide to successful bioprospecting: informed by actinobacterial systematics. Antonie Van Leeuwenhoek 98:119-142

Kim SJ, Lim JM, Ahn JH et al (2014) Description of Galbitalea soli gen. nov., sp. nov., and Frondihabitans sucicola sp. nov. Int J Syst Evol Microbiol 64:572-578

Kutzner HJ (1981) The family Streptomycetaceae. In: Starr MP, Stolp H, Trüper HG, Balows A, Schlegel HG (eds) The prokaryotes-a handbook on habitats, isolation and identification of bacteria. Springer, Berlin, pp 2028-2090

Kuykendall LD, Roy MA, O’Neill JJ, Devine TE (1988) Fatty acids, antibiotic resistance, and deoxyribonucleic acid 
homology groups of Bradyrhizobium japonicum. Int J Syst Bacteriol 38:358-361

Li HR, Yu Y, Luo W, Zeng YX (2010) Marisediminicola antarctica gen. nov., sp. nov., an actinobacterium isolated from the Antarctic. Int $J$ Syst Evol Microbiol 60:2535-2539

Männistö MK, Schumann P, Rainey FA et al (2000) Subtercola boreus gen. nov., sp. nov. and Subtercola frigoramans sp. nov., two new psychrophilic actinobacteria isolated from boreal groundwater. Int $\mathrm{J}$ Syst Evol Microbiol 50:1731-1739

Miller LT (1982) Single derivatization method for routine analysis of bacterial whole-cell fatty acid methyl esters, including hydroxy acids. J Clin Microbiol 16:584-586

Peeters K, Ertz D, Willems A (2011) Culturable bacterial diversity at the Princess Elisabeth Station (Utsteinen, Sør Rondane Mountains, East Antarctica) harbours many new taxa. Syst Appl Microbiol 34:360-367

Pruesse E, Peplies J, Glöckner FO (2012) SINA: accurate highthroughput multiple sequence alignment of ribosomal RNA genes. Bioinformatics 28:1823-1829

Rosselló-Móra R, Trujillo ME, Sutcliffe IC (2017) Introducing a digital protologue: a timely move towards a database-driven systematics of archaea and bacteria. Syst Appl Microbiol 40:121-122

Saitou N, Nei M (1987) The neighbour-joining method: a new method for reconstructing phylogenetic trees. Mol Biol Evol 4:406-425

Schaeffer AB, Fulton MD (1933) A simplified method of staining endospores. Science 77:194

Schleifer KH (1985) Analysis of the chemical composition and primary structure of murein. Methods Microbiol 18:123-156
Schumann P (2011) Peptidoglycan structure. Methods Microbiol 38:101-129

Schumann P, Behrendt U, Ulrich A, Suzuki KI et al (2003) Reclassification of Subtercola pratensis Behrendt et al. 2002 as Agreia pratensis comb. nov. Int J Syst Evol Microbiol 53:2041-2044

Si H, Shi F, Zhang L et al (2017) Subtercola lobariae sp. nov., an actinobacterium of the family Microbacteriaceae isolated from the lichen Lobaria retigera. Int J Syst Evol Microbiol 67:1516-1521

Singh P, Hanada Y, Singh SM, Tsuda S (2014) Antifreeze protein activity in Arctic cryoconite bacteria. FEMS Microbiol Lett 351:14-22

Tamura K, Stecher G, Peterson D et al (2013) MEGA6: molecular evolutionary genetics analysis version 6.0. Mol Biol Evol 30:2725-2729

Tindall BJ (1990a) Lipid composition of Halobacterium lacusprofundi. FEMS Microbiol Lett 66:199-202

Tindall BJ (1990b) A comparative study of the lipid composition of Halobacterium saccharovorum from various sources. Syst Appl Microbiol 13:128-130

Tindall BJ, Sikorski J, Smibert RA, Krieg NR (2007) Chapter 15: phenotypic characterization and the principles of comparative systematics. In: Reddy C, Beveridge T, Breznak J, Marzluf G, Schmidt T, Snyder L (eds) Methods for general and molecular microbiology, 3rd edn. ASM Press, Washington, DC, pp 330-393

Zhang L, Xu Z, Patel BKC (2007) Frondicola australicus gen. nov., sp. nov., isolated from decaying leaf litter from a pine forest. Int J Syst Evol Microbiol 57:1177-1182

Zhang DC, Brouchkov A, Griva G, Schinner F, Margesin R (2013) Isolation and characterization of bacteria from ancient Siberian permafrost sediment. Biology 2:85-106 